\title{
Tinjauan Yuridis Penyelesaian Kerugian Daerah Melalui Penyetoran Ke Kas Negara
}

\author{
Andri Idrus \\ Magister Hukum Fakultas Hukum Universitas Islam Indonesia Yogyakarta Indonesia \\ Jln. Cik Di Tiro No. 1 Yogyakarta Indonesia \\ 17912079@students.uii.ac.id
}

\begin{abstract}
Regional losses are a subsystem of the concept of state losses based on the concept of state finances which are expressly stated in the Constitution. So far, the settlement of regional losses by the Regional Government is carried out through deposits to the regional treasury, although this is not explicitly stated in the legislation. This study aims to examine the legal consequences of settlement of regional losses through deposits to the state treasury. This study uses a normative legal research method with statutory and conceptual approaches. The results of the study conclude that there is no firm norm that stipulates the obligation to settle regional losses through depositing them into the regional treasury, so that the discourse on the settlement of regional losses through deposits to the state treasury is valid and possible.
\end{abstract}

Key Words: Finance; regional finance; treasury fund

\begin{abstract}
Abstrak
Kerugian daerah merupakan subsistem dari konsep kerugian negara yang berinduk dari konsep keuangan negara yang secara tegas termaktub dalam konstitusi. Selama ini penyelesaian kerugian daerah oleh Pemerintah Daerah dilakukan melalui penyetoran ke kas daerah, meskipun hal tersebut tidak secara tegas dinyatakan dalam peraturan perundangan. Penelitian ini bertujuan untuk mengkaji akibat hukum penyelesaian kerugian daerah melalui penyetoran ke kas negara. Penelitian ini menggunakan metode penelitian hukum normatif dengan pendekatan perundang-undangan dan konseptual. Hasil penelitian menyimpulkan bahwa belum terdapatnya norma yang tegas yang mengatur keharusan penyelesaian kerugian daerah melalui penyetoran ke kas daerah, sehingga diskursus penyelesaian kerugian daerah melalui penyetoran ke kas negara menjadi sah dan mungkin.
\end{abstract}

Kata-kata Kunci: Keuangan; keuangan daerah; kas negara 


\section{Pendahuluan}

Undang-Undang Dasar 1945 Pasal 23 ayat (1) berbunyi: "Anggaran pendapatan dan belanja negara sebagai wujud dari pengelolaan keuangan negara ditetapkan setiap tahun dengan Undang-undang dan dilaksanakan secara terbuka dan bertanggung jawab untuk sebesar besarnya kemakmuran rakyat". Dalam pasal ini secara eksplisit disebutkan ada dua faktor penentu bagi tercapainya kemakmuran rakyat melalui pengelolaan keuangan yang baik, yaitu terbuka atau transparan dan bertanggung jawab atau akuntabel. Hal ini sesuai dengan visi BPK untuk menjadi lembaga pemeriksa keuangan negara yang kredibel dengan menjunjung tinggi nilai-nilai dasar untuk berperan aktif dalam mendorong terwujudnya tata kelola keuangan negara yang akuntabel dan transparan.

Akuntabel dan transparan seperti layaknya pilar yang menopang tata kelola keuangan yang baik sehingga tercipta kemakmuran rakyat. Stewart dalam teorinya Stewart's Ladder of Accountability mengemukakan bahwa untuk menjadi akuntabel perlu melewati langkah-langkah dimana langkah yang pertama adalah probity dan legality. Probity diharapkan dapat dipenuhi dari audit laporan keuangan, sedangkan legality merupakan kepatuhan terhadap peraturan Perundangan-undangan yang berlaku dalam mengelola keuangan. Diperolehnya opini Wajar Tanpa Pengecualian (WTP) adalah merupakan awal dari proses tercapainya akuntabilitas secara penuh. Dalam era otonomi daerah ini, pengelolaan keuangan daerah menjadi salah satu faktor yang krusial dalam pertanggungjawaban pejabat publik daerah kepada masyarakat. Laporan Keuangan Pemerintah Daerah (LKPD) yang diterbitkan setiap tahun oleh pemerintahdaerah (Pemda) merupakan salah satu pertanggungjawaban formal Pemda dalam pengelolaan keuangan daerah. Amanah Undang-Undang (UU) Nomor 1 Tahun 2004 menyatakan bahwa LKPD tersebut wajib diaudit oleh BPK. ${ }^{1}$

Pemeriksaan atas pengelolaan keuangan negara dilakukan sebagai bentuk pengawasan agar tidak terjadi kecurangan (fraud) (PermenPAN, 2008). Fraud bisa terjadi di sektor pemerintah maupun sektor swasta. Kecurangan yang terjadi di sektor pemerintahan atau lebih dikenal dengan nama korupsi, menurut UndangUndang Nomor 31 Tahun 1999 adalah kegiatan melawan hukum, melakukan perbuatan dengan tujuan memperkaya diri sendiri atau orang lain atau suatu korporasi yang mengakibatkan kerugian keuangan negara atau perekonomian negara. Korupsi umumnya didefinisikan sebagai penyalahgunaan posisi atau sumber daya umum untuk keuntungan pribadi (Sandholtz \& Koetzle, 2000).

${ }^{1}$ Bahrullah akbar dan Achmad Djazuli, “Audit Keuangan dan Kesejahteraan rakyat studi pada Kabupaten Badung, Tabanan Dan Kota Denpasar Tahun 2013”, Jurnal Tata kelola \& Akuntabilitas Kenangan Negara. Volume 1. Nomor 1. Juli 2015, hlm. 2 
Kondisi korupsi di Indonesia dapat dilihat dari berbagai sumber, salah satunya dari Transparancy Internasional (TI), sebuah organisasi masyarakat internasional Anti Korupsi yang mengeluarkan Indeks Persepsi Korupsi (IPK) negara atau Corruption Perception Index (CPI). CPI merupakan suatu indeks gabungan yang mengukur tingkat persepsi korupsi sektor publik pada negara-negara di dunia. CPI digunakan dengan membandingkan kondisi korupsi disuatu negara terhadap negara lain. Perkembangan indeks persepsi korupsi Indonesia dalam lima tahun terakhir menunjukkan bahwa Indonesia merupakan 80 negara terkorup didunia dan untuk wilayah ASEAN, Indonesia masih dipandang sebagai negara yang rawan korupsi atau nomor 2 terkorup dibandingkan negara tetangga. Negara terbersih di wilayah ASEAN secara berurutan yaitu Singapura, Brunei Darusalam, Malaysia, Thailand, Indonesia dan Myanmar. ${ }^{2}$

Berdasarkan ketentuan Pasal 1 ayat (3) UUD Negara Republik Indonesia Tahun 1945. "Negara Indonesia adalah Negara Hukum "yang menganut desentralisasi dalam penyelenggaraan pemerintahan, Sebagaimana diisyaratkan dalam Pasal 18 ayat (1) UUD Negara Republik Indonesia 1945 “Negara Kesatuan Republik Indonesia dibagi atas daerah-daerah provinsi dan daerah provinsi itu dibagi atas kabupaten dan kota mempunyai pemerintah daerah, yang diatur dengan undang-undang". Sebagai negara hukum, setiap penyelenggaraan urusan pemerintahan haruslah berdasarkan pada hukum yang berlaku (wetmatigheid van bestuur). Sebagai negara yang menganut desentralisasi mengandung arti bahwa urusan pemerintahan itu terdiri atas pemerintahan pusat dan urusan pemerintahan daerah. Artinya ada perangkat pemerintah pusat dan urusan pemerintah daerah. Artinya ada perangkat pemerintah pusat dan ada perangkat pemerintah daerah, yang diberi otonomi yakni kebebasan dan kemandirian untuk mengatur dan mengurus urusan rumah tangga daerah. ${ }^{3}$

Salah satu kebijakan pemerintah daerah dalam era otonomi daerah adalah pengelolaan keungan daerah melalui desentralilasi fiskal (fiscal decentralization) berdasarkan Undang-Undang No. 32 Tahun 2004 tentang pemerintah daerah jo. Undang-Undang No. 33 Tahun 2004 tentang perimbangan pemerintah pusat dan pemerintah daerah yang mencakup tiga aspek penting, yakni: (1) Hak dan kewenangan daerah untuk mengelola pajak dan retribusi daerah; (2) Hak dan kewenangan daerah untuk mengelola dana perimbangan; dan (3) Hak dan kewenangan daerah untuk mengelola pinjaman daerah. Penyerahan kewenangan

2 Nurhasanah, "Efektivitas Pengendalian Internal, Audit Internal, Karakteristik Instansi dan Kasus Korupsi (Studi Empiris di Kementerian/Lembaga)", Jurnal Tata Kelola \& Akuntabilitas Keuangan Negara, Volume 2. Nomor 1 Tahun 2016, hlm. 2.

${ }_{3}^{3}$ Ridwan HR, Hukum Administrasi Negara Edisi revisi, Penerbit Rajawali pers, cet. 14, Jakarta, 2018, hlm. 17. 
pusat kepada daerah untuk menggali sumber-sumber pendapatan, hak untuk mengelola transfer, dan hak untuk mengelola pinjaman daerah harus dapat meningkatkan investasi yang sehat dan dinamis, mempercepat pertumbuhan ekonomi, pengentasan kemiskinan, menyediakan lapangan kerja, dan untuk mencapai tujuan negara. Desentralisasi fiskal merupakan bagian dari politik hukum bidang pengelolaan keuangan negara yang bertujuan untuk mewujudkan kesejahteraan rakyat. Atas dasar penyerahan kewenangan tersebut, kepala daerah diberikan hak dan wewenang untuk mengelola keuangan daerah berdasarkan tata kelola keungan yang baik dan tertib (good financial governance). Tata kelola keuangan daerah yang baik dan tertib mengaharuskan pemerintah daerah mengedepankan empat aspek penting yakni: (1) adanya partisipasi masyarakat dalam pengeloalaan keuangan; (2) adanya transparansi atau keterbukaan dalam pengelolaan; (3) adanya akuntabilitas atau pertanggung jawaban dalam pengelolaan; dan (4) adanya keadilan anggaran dalam pengelolaan. ${ }^{4}$

Kelemahan perundang-undangan dalam bidang keuangan negara menjadi salah satu penyebab terjadinya beberapa bentuk penyimpangan dalam pengelolaan keuangan negara. Dalam upaya menghilangkan penyimpangan tersebut dan mewujudkan sistem pengelolaan fiskal yang berkesinambungan (sustainable) sesuai dengan aturan pokok yang telah ditetapkan dalam UndangUndang Dasar dan asas-asas umum yang berlaku secara universal dalam penyelenggaraan pemerintahan negara diperlukan suatu undang-undang yang mengatur pengelolaan keuangan negara. Upaya untuk menyusun undangundang yang mengatur pengelolaan keuangan negara telah dirintis sejak awal berdirinya negara Indonesia. Oleh karena itu, penyelesaian Undang-undang tentang Keuangan Negara merupakan kelanjutan dan hasil dari berbagai upaya yang telah dilakukan selama ini dalam rangka memenuhi kewajiban konstitusional yang diamanatkan oleh Undang-Undang Dasar 1945. Sebagai suatu negara yang berkedaulatan rakyat, berdasarkan hukum, dan menyelenggarakan pemerintahan negara berdasarkan konstitusi, sistem pengelolaan keuangan negara harus sesuai dengan aturan pokok yang ditetapkan dalam UndangUndang Dasar. Dalam Undang-Undang Dasar 1945 Bab VIII Hal Keuangan, antara lain disebutkan bahwa anggaran pendapatan dan belanja negara ditetapkan setiap tahun dengan undang-undang, dan ketentuan mengenai pajak dan pungutan lain yang bersifat memaksa untuk keperluan negara serta macam dan harga mata uang ditetapkan dengan Undang-Undang.

${ }^{4}$ Karianga Hendra, Politik Hukum dalam Pengelolaan Keuangan Daerah, Kencana Cetakan ke-1, Jakarta, 2013, 


\section{Rumusan Masalah}

Berdasarkan latar belakang di atas, maka rumusan masalah dalam penelitian ini yaitu bagaimana akibat hukum penyelesaian kerugian daerah melalui penyetoran ke kas negara?

\section{Tujuan Penelitian}

Berdasarkan rumusan masalah di atas, maka tujuan penelitian ini yaitu untuk mengetahui akibat hukum penyelesaian kerugian daerah melalui penyetoran ke kas negara?

\section{Metode Penelitian}

Penelitian ini merupakan jenis penelitian normatif yaitu penelitian hukum yang mengacu pada pendekatan peraturan perundangan-undangan tertulis atau bahanbahan hukum yang lain. Penelitian hukum dengan cara mempelajari hukum positif yang tertulis dalam hal ini yaitu peraturan perundang-undangan dengan cara meneliti hukum yang terdiri bahan hukum primer, dan bahan hukum sekunder. Dengan menggunakan pendekatan perundang-undangan dan konseptual. ${ }^{5}$

\section{Hasil Penelitian dan Pembahasan}

\section{Akibat Hukum Kerugian Keuangan Daerah terhadap Kas Negara dan Kewenangan Pengelolaan Keuangan Negara}

Hubungan keuangan antara pemerintah pusat dan daerah dapat diartikan sebagai suatu sistem yang mengatur bagaimana caranya sejumlah dana dibagi antara berbagai tingkat pemerintah, serta bagimana caranya mencari sumbersumber pembiayaan daerah untuk menunjang kegiatan-kegiatan sektor publiknya. Perimbangan keuangan antara pemerintah pusat dan daerah adalah suatu sistem pembiayaan pemerintahan dalam kerangka negara kesatuan, yang mencakup pembagian keuangan antara pemerintah pusat dan daerah serta pemerataan antar daerah secara proposional, demokratis, adil dan transparan dengan memperhatikan potensi, kondisi, dan kebutuhan daerah, sejalan dengan kewajiban dan pembagian kewenangan serta tata cara penyelenggaraan kewenangan tersebut. Instrumen yang dipergunakan dalam perimbangan keuangan antara pusat dan daerah adalah.

1. Dana perimbangan yaitu, dana yang bersumber dari penerimaan APBN yang dialokasikan kepada daerah untuk membiayai kebutuhan daerah dalam rangka pelakasanaan desentralisasi;

\footnotetext{
${ }^{5}$ H. Ali Zainuddin, Metode Penelitian Hukum, Sinar Grafika, Jakarta, 2011, hlm. 12.
} 
2. Dana alokasi umum (DAU), yaitu, dana yang berasal dari APBN, yang dialokasikan dengan tujuan pemerataan kemampuan keuangan antardaerah untuk membiayai kebutuhan pengeluaraanya dalam rangka pelaksanaan desentralisasi;

3. Dana alokasi khusus (DAK), yaitu, dana yang berasal dari APBN, Yang dialokasikan kepada daerah untuk membantu membiyai kebutuhan tertentu;

4. Dana bagi hasil, yaitu, pembagian hasil penerimaan dari (1) SDA dari, antara lain, minyak bumi, gas, alam, pertambangan umum, kehutanan, dan perikanan dan (2) penerimaan perpajakan (tax sharing) dari antara lain, pajak perseorangan (PPh) pajak bumi dan bangunan (PBB), dan bea perolehan hak atas dan bangunan (BPHTB).

5. Pengaturan relasi keuangan pemerintah pusat dan daerah, yang antara lain dilaksanakan melalui dana perimbangan keuangan pemerintah pusat dan daerah (PKPD) adalah:

a. Dalam rangka pemberdayaan (empowerment) masyarakat dan pemerintah daerah agar tidak tertinggal di bidang pembangunan,

b. Untuk mengintensifkan aktivitas dan kreativitas perekonomian masyarkat daerah yang berbasis pada potensi yang dimiliki setiap daerah. Pemda dan DPRD bertindak sebagai fasilitator dalam pembangunan ekonomi yang dilakukan oleh rakyatnya artinya, dalam era otda, rakyat harus berperan aktif dalam perencanaan dan pelaksanaan pembangunan daerahnya,

c. Mendukung terwujudnya good governance oleh pemda melalui perimbangan keuangan secara transparan, dan

d. Untuk menyelenggarakan otda secara demokratis, efektif, dan efisien dibutuhkan SDM yang profesional, memiliki moralitas yang baik. Oleh sebab itu, desentralisasi fiskal yang dilaksanakan melalui perimbangan keuangan akan meningkatkan kemampuan daerah dalam membangun dan pemberian pelayanan kepada masyarakat daerah, bukan hanya sekedar pembagian dana, lalu terjadi "desentralisasi $\mathrm{KKN}$ " dari pusat ke daerah. ${ }^{6}$

Pengelolaan keuangan negara dalam perspektif negara hukum sosial atau sering disebut dengan welfare state atau verzor gingsstaat merupakan amanah dari Pasal 23, 23A-G dan Pasal 33 UUD Negara RI 1945 Keuangan negara dalam perspektif konstitusi harus mencerminkan prinsip-prinsip:

1. Keterbukaan (openness) dan pertanggungjawaban (accountability) untuk sebesar-besarnya kemakmuran rakyat.

2. Demokrasi dalam prosedur (persetujuan parlemen) dan demokrasi dalam substansi (setiap mata anggaran mencerminkan kehendak rakyat).

3. Pengawasan secara auditif (oleh BPK) dan pengawasan secara politik (oleh DPR).

${ }^{6}$ W. Riawan Tjandra, Hukum Keuangan Negara, PT Grasindo, Jakarta, 2009, hlm. 105-106. 
4. Prinsip efisiensi berkeadilan

5. Keseimbangan dalam kesatuan ekonomi nasional

6. Kesinambungan (sustainability).

Keseluruhan prinsip tersebut dijabarkan lebih lanjut dalam pengeloaan keuangan negara dan perbendaharaan negara. Undang-Undang No. 17 Tahun 2003 tentang keuangan negara menerangkan seluruh prinsip tersebut dalam pengelolaan negara berdasarkan asas-asas umum pengelolaan keuangan negara yang mencerminkan best practices dalam pengelolaan keuangan negara yang terdiri dari:

1. Akuntabilitas berorientasi pada hasil.

2. Profesionalitas

3. Proposionalitas

4. Keterbukaan dalam pengelolaan keuangan negara

5. Pemeriksaan keuangan oleh badan pemeriksa yang bebas dan mandiri.

Asas-asas baru pengeloalaan keuangan negara itu melengkapi asas-asas pengeloalaan keuangan negara yang suda ada, yaitu: asas tahunan, asas universalitas, asas kesatuan dan asas spesailitas. Pengelolaan keuangan negara berdasrkan Undang-Undang No. 17 Tahun 2003 tentang keuangan negara dan Undang-Undang No. 1 Tahun 2004 tentang perbendaharaan negara dilaksanakan berdasarkan beberapa prinsip, yaitu:

1. Prinsip anggaran berbasis kinerja/prestasi kerja (performa budgeting).

2. Kerangka pengeluaran jangka menengah (Medium Term Expenditure).

3. Keterkaitan antara sistem penganggaran dengan sistem perencanaan.

Guna mewujudkan sistem pengelolaan keuangan negara yang bersendikan asas-asas pengelolaan keuangan yang baik (good financial governance), diperlukan pengelolaan keuangan negara yang mampu merealisasikan prinsip-prinsip pengelolaan keuangan negara tersebut melalui sistem penganggaran yang dilaksanakan berdasarkan prinsip kehati-hatian dan kecermatan. ${ }^{7}$

Dalam sistem keuangan negara yang didasarkan atas paradigma anggaran berbasis prestasi kerja/kinerja (performa budgeting), dilakukan pembagian antara kewenangan pengurusan administratif (administrtieve beheer) dan pengurusan perbendaharaan (comptabel beheer). Menteri tekhnis menjalankan kewenangan administratif dalam sistem pengelolaan keuangan negara yang diberikan kewenangan dalam pembuatan komitmen, pengujian dan pembebanan serta perintah bayaran. Dalam paradigma pengelolaan keuangan negara modern menteri tekhnis berkedudukan sebagai chief organizational officer (COO). Untuk 
kementrian yang dipimpinnya. Menteri keuangan menjalankan kewenangan perbendaharaan dalam pengelolaan keuangan negara yang diberikan kewenangan untuk melaksanakan pengujian dan pencairan dana. Kedudukan menteri keuangan (Menkeu) adalah sebagai chief financial officer (CFO) Pemerintah RI. Pengaturan kewenangan menteri tekhnis dan menteri keuangan dalam Undang-Undang No. 17 Tahun 2003 dan Undang-Undang No. 1 Tahun 2004 diderivasikan dari kedudukan menteri tekhnis dan menteri keuangan sebagai $\mathrm{COO}$ dan $\mathrm{CFO}$ dalam sistem keuangan negara modern tersebut.

Dalam kepustakaan hukum keuangan negara, kedudukan Menteri tekhnis tersebut merupakan otorisator, yaitu pejabat yang mempunyai wewnang untuk mengambil tindakan/keputusan yang dapat menyebabkan uang negara keluar/masuk, sehingga menjadi berkurang atau bertambah karena pungutan dari masyarakat. Sedangkan menteri keuangan merupakan ordonator, yaitu pejabat yang mempunyai wewenang untuk melakukan pengawasan terhadap otorisator agar otorisator dalam melakukan tindakan selalu mematuhi peraturan perundang-undangan dan sesuai kepentingan umum. ${ }^{8}$

\section{Konsekuensi Kerugian Keuangan Daerah terhadap Kas Negara}

Pengelolaan Keuangan negara didasarkan atas legal framework di pusat dan daerah. Di pusat landasan hukum pengelolaan keuangan negara antara lain meliputi:

1. Undang-Undang Dasar Negara RI 1945

2. Undang-Undang No. 17 Tahun 2003 tentang Keuangan Negara

3. Undang-Undang No. 1 Tahun 2004 tentang Perbendaharaan Negara

4. Undang-Undang No. 15 Tahun 2004 tentang Pemeriksaan Pengelolaan Dan Tanggung Jawab Keuangan Negara

5. Undang-Undang Propenas

6. Undang-Undang APBN

7. PP No. 20 Tahun 2004 tentang Rencana Kerja Pemerintah

8. PP No. 21 Tahun 2004 tentang Penyusunan Rencana Kerja Dan Anggaran Kementrian Negara/Lembaga

9. Perpres Pelaksanaan APBN

10. Perpres Rencana Pembangunan Tahunan.

Pemerintah yang didesentralisasi (decentralized goverment), juga mengharuskan adanya legal framework keuangan daerah yang menjabarkan kewenangan-kewenangan pemerintah daerah dalam pengelolaan keuangan negara dengan keuangan daerah. 
Penjelasan umum angka 6 UU Nomor 32 Tahun 2004 menyatakan bahwa kekuasaan pengelolaan keuangan negara adalah sebagai bagian dari kekuasaan pemerintahan. Kekuasaan pengelolaan keuangan negara dari presiden sebagian diserahkan kepada Gubernur/Bupati/Walikota, selaku kepala pemerintah daerah dalam pemilikan kekayaan daerah yang dipisahkan. Ketentuan tersebut berimplikasi terhadap pengaturan pengelolaan daerah, yaitu bahwa Gubernur/Bupati/Walikota bertanggung jawab atas pengelolaan daerah sebagi bagian dari kekuasaan pemerintahan daerah, yaitu dalam Undang-undang mengenai pemerintahan daerah. Dengan demikian dasar hukum pengelolaan keuangan daerah antara lain adalah:

1. UU Pemerintah derah

2. UU perimbangan keuangan antara pemerintah pusat dan daerah

3. Perda APBD. ${ }^{9}$

Bidang pengelolaan keuangan negara yang luas dapat dikelompokan kedalam sub-bidang, sebagai berikut:

\section{Sub-bidang pengelolaan fiskal}

Bahwa baik pengeluaran maupun penerimaan pemerintah pasti mempunyai pengaruh atas pendapatan nasional. Pengeluaran pemerintah dapat memiliki pengaruh yang bersifat memperbesar pendapatan nasional (expansionary), tetapi penerimaan pemerintah dapat mengurangi pendapatan nasional (contarctionary). Pengaruh pengeluaran pemerintah terhadap pendapatan nasional tergantung pada jenis pengeluaran, sedang untuk penerimaan pemerintah pengaruhnya tergantung pada jenis sumber penerimaan itu. Seperti, bahwa perpajakan sebagai sumber penerimaan pemerintah lebih bersifat memperkecil pendapatan nasional dibanding dengan pinjaman negara; dan pinjaman dan pinjaman negara lebih bersifat memperkecil pendapatan dibanding dengan pencetak uang baru sebagai sumber penerimaan negara, kesadaran terhadap pengaruh dan penerimaan pemerintah belum lama muncul dalam dunia ilmu pengetahuan. Tetapi dengan disadarinya pengaruh-pengaruh penerimaan dan pengeluaran pemerintah tersebut, timbulah gagasan untuk dengan sengaja mengubah-ubah pengeluaran dan penerimaan pemerintah guna mencapai kestabilan ekonomi teknik mengubah pengeluaran dan penerimaan pemerintah inilah yang kita yang kenal kebijakan fiskal atau politik fiskal, dalam perkembangannya kebijakan fiscal dalam perkembangannya kebijakan fiscal dapat dibedakan menjadi 4 macam, atas dasar.

a. Pembiyaan fungsional (functional finance)

Tokoh dari kebijakan fiscal jenis adalah A.P. Lerne. Dalam hal ini pengeluaran pemerintah ditentukan dengan melihat akibat-akibat tidak 
langsung terhadap pendapatan nasional terutama guna meningkatkan penerimaan pemerintah, sehingga pada saat ada pengganguran, pajak sama sekali tidak perlukan. Selanjutnya pinjaman akan dipakai sebagai alat untuk menekan inflasi lewat pengurangan dana yang tersedia dalam masyarakat. Kemudian apabila pajak maupun pinjaman dirasa tidak tepat, maka ditempulah pencetakan uang. Jadi pengeluaran pemerintah dan perpajakan dipertimbangkan sebagai suatu hal yang terpisah, namun demikian ada kekhawatiran bahwa tanpa ada hubungan langsung keduanya akan ada bahanya karena kemungkinan pengeluaran pemerintah semakin berlebihan. ${ }^{10}$

b. Pendekatan ini lebih banyak disukai dari pada pendekatan "pembelajaran fungsional" karena pengeluaran pemerintah, perpajakan dan pinjaman dimaksudkan untuk mencapai kestabilan ekonomi yang lebih mantap. Dalam pendekatan ini, hubungan langsung antara pengeluaran pemerintah dan perpajakan selalu dipertahankan, tetapi penyesuaian dalam anggaran selalu dibuat guna memperkecil ketidak stabilan ekonomi, sehingga pada suatu saat dapat terjadi deficit maupun surplus. Tokoh pendekatan ini adalah Alvin hansen, yang menyarankan bahwa dalam masa depresi di mana ada banyak pengangguran, pengeluaran pemerintah yang meningkat adalah satu-satunya obat. ${ }^{11}$

\section{Dilema Penyelesaian Kerugian Keuangan Daerah}

Pada umumnya, hubungan antara pemerintah pusat dan daerah terefleksi dalam intergovernmental fiscal relation. Pelimpahan tugas kepada pemerintah daerah dalam otonomi harus disertai dengan pelimpahan keuangan (Money follows function) Pendelegasian pengeluaran (Expenditure assignment) sebagai konsekuensi diberikanya kewenangan yang luas serta Tanggung jawab pelayanan publik tentunya harus diikuti dengan adanya pendelegasian pendapatan (refenue assignment). Tanpa pelimpahan ini, otonomi daerah menjadi tidak bermakna. Seiring dengan perkembangan waktu, Masalah hubungan keuangan dan pembagian wewenang antara pemerintah pusat dan daerah tersebut pada akhirnya sangat tergantung pada tingkatan atau derajat desentralisasi (degre of decentralization) yang tercermin dalam pembagian kewenangan antara pemerintah pusat dan daerah.

Apabila derajat desentralisasinya rendah (dekonsentrasi dominan), maka Pemerintah pusat akan memegang kendali utama dalam perencanaan dan penggangaran pembangunan daerah. Sebaliknya apabila tingkatan desentraslisasinya tinggi (desentralisasi dominan), maka Pemerintah daerah yang bertanggung jawab penuh dalam perencanaan dan penganggaran pembangunan

\footnotetext{
${ }^{10}$ Mustaqiem., Hukum Kenangan Negara, Mata Padi Presindo, Yogyakarta, hlm. 36.

${ }^{11}$ Ibid., hlm. 38
} 
di daerah. Adanya kaitan yang erat antara kegiatan pemerintahan dengan sumber pembiayaan pada hakekatnya memberikan petunjuk bahwa pengaturan hubungan keuangan pusat dan daerah tidak terlepas dari masalah pembagian tugas antara pemerintahan pusat dan daerah. ${ }^{12}$

Karena itu, untuk melihat suatu sistem hubungan keuangan pusat dan daerah perlu dilihat dari keseleruhan tujuan hubungan keuangan pusat dan daerah. Dalam hal ini, ada empat kriteria yang perlu diperhatikan untuk menjamin adanya sistem hubungan keuangan pusat dan daerah, yaitu:

a. Sistem tersebut seharusnya memberikan distribusi kekuasaan yang rasional diantara berbagai tingkat pemerintah mengenai penggalian sumber dana pemerintah dan kewenangan penggunaanya, yaitu suatu pembagian yang sesuai pola umum desentralisasi.

b. Sistem tersebut seharusnya menyajikan suatu bagian yang memadai dari sumber-sumber dana masyarakat secara keseluruhan untuk membiayai pelaksanaan fungsi-fungsi penyediaan pelayanan dan pembangunan yang diselenggarakan oleh pemerintah daerah;

c. Sistem tersebut seharusnya sejauh mungkin mendistribusikan pengeluaran pemerintah secara adil di antara daerah-daerah, atau sekurang-kurangnya memberikan prioritas pada pemerataan pelayanan kebutuhan dasar tertentu;

d. Pajak dan retribusi yang dikenakan oleh pemerintah daerah harus sejalan dengan distribusi yang adil atas beban keseluruhan dari pengeluaran pemerintah dalam masyarakat.

Masalah hubungan keuangan antara Pusat dengan Daerah dapat dipecahkan dengan sebaik-baiknya hanya apabila masalah pembagian tugas dan kewenangan antara pusat dan daerah juga dpecahkan dengan jelas. Pemerintah daerah sudah tentu harus memiliki kewenangan membelanjakan sumber-sumber daya keuangannya agar dapat menjalankan fungsi-fungsi yang menjadi tanggungjawabnya.

Dalam praktek, kebebasan ini dapat terbatas bila sumber-sumber pendapatan yang diserahkan kepada mereka oleh konstitusi tidak mencukupi untuk menjelaskan fungsi-fungsi, sehingga ketergantungan mereka kepada subsidi dari pemerintah pusat. ${ }^{13}$

Dalam rangka menyelenggarakan pemerintahan, pelayanan masyarakat, dan pembangunan, maka pemerintahan suatu negara pada hakekatnya mengemban tiga fungsi utama, yakni: fungsi alokasi, yang meliputi antara lain, sumber-sumber ekonomi dalam bentuk barang dan jasa pelayanan masyarakat; fungsi distribusi,

\footnotetext{
12 Ni'matul Huda., Hukum Pemerintahan Daerah, Nusa Media, Bandung, 2016, hlm. 16.

${ }^{13}$ Ibid., hlm. 17
} 
yang meliputi antara lain, pendapatan dan kekayaan masyarakat, pemerataan pembangunan; dan fungsi stabilisasi, yang meliputi antara lain PertahananKeamanan, Ekonomi dan moneter. Fungsi distribusi dan fungsi stabilisasi pada umumnya lebih efektif dilaksanakan oleh pemerintah Daerah karena Daerah pada Umumnya lebih mengetahui kebutuhan serta standar pelayanan masyarakat. Dengan demikian, pembagian ketiga fungsi dimaksud sangat penting sebagai landasan dalam penentuan dasar-dasar perimbangan keuangan antara Pemerintah Pusat dan Pemerintah Daerah secara jelas dan tegas. ${ }^{14}$

Undang-Undang Nomor 1 Tahun 2004 mendefinisikan kas Negara sebagai “Tempat penyimpanan uang negara yang ditentukan oleh menteri keuangan selaku bendahara umum negara untuk menampung seluruh penerimaan negara dan membayar seluruh pengeluaran Negara" dan kas Daerah sebagai "tempat penyimpanan uang Daerah yang ditentukan oleh Gubernur/ Bupati/Walikota untuk menampung seluruh penerimaan daerah dan membayar seluruh pengeluaran daerah". Berdasarkan hal tersebut, kerugian daerah yang disetor ke kas daerah dianggap sebagai penerimaan daerah yang merupakan bagian dari siklus APBD. Akan tetapi, tidak terdapat ketentuan dalam paket Undang-undang keuangan negara yang secara gamblang menyebut bahwa kerugian daerah wajib disetor ke kas daerah. PP Nomor 38 Tahun 2016 sebagai aturan pelaksana dari Pasal 63 UU Nomor 1 Tahun 2004 adalah satu-satunya aturan yang sejauh ini penulis anggap cukup, dalam membuat dikotomi antara tata cara penyelesaian kerugian negara dan tata cara penyelesaian kerugian daerah. Akan tetapi, aturan tersebut masih belum menyatakan secara tegas soal apakah kerugian daerah wajib disetor ke kas daerah. Pasal 41 PP Nomor 38 Tahun 2016 menyatakan, berdasarkan surat penagihan pihak yang merugikan/pengampu/yang memperoleh hak/ahli waris menyetorkan ganti kerugian negara/daerah ke kas negara/daerah. Selain itu, PP Nomor 38 Tahun 2016 hanya berlaku untuk kerugian negara/daerah yang subjeknya pegawai negeri bukan bendahara atau pejabat lain. Sementara itu, sesuai dengan Pasal 62 UU Nomor 1 Tahun 2004 dan Pasal 22 ayat (4) UU Nomor 15 Tahun 2004, penyelesaian kerugian negara/daerah yang subjeknya bendahara tunduk pada Peraturan BPK Nomor 3 Tahun 2007 tentang Tata Cara Penyelesaian Ganti Kerugian Negara terhadap Bendahara.

\section{Penutup}

Berdasarkan uraian di atas, maka dapat disimpulkan bahwa penyelesaian kerugian daerah melalui penyetoran ke kas negara menjadi sah dan mungkin 
karena dua argumen pokok berikut. Pertama, konstitusi tidak mengenal istilah Keuangan daerah dan hanya menyebut keuangan negara. Sebagaimana dijelaskan pada bagian sebelum ini, berdasarkan Peraturan Perundang-Undangan, Keuangan daerah merupakan subsistem dari Keuangan Negara dan kekuasaan pengelolaan keuangan negara oleh pemerintah daerah dalam wujud keuangan daerah, Sejatinya merupakan hak pemberian, bukan hak yang pada awalnya benar-benar dimiliki atau inheren pada pemerintah daerah. Kedua, karena keuangan daerah merupakan subsistem dari Keuangan Negara, maka kerugian daerah sebagai turunan dari keuangan daerah dengan sendirinya merupakan bagian dari keuangan negara, sehingga penyelesaian kerugian daerah melalui penyetoran ke kas negara menjadi sah dan mungkin. Penyetoran kerugian daerah ke kas negara adalah semacam "Sanksi Konstitusional" yang akan meneguhkan konsep negara kesatuan yang dianut oleh Republik Indonesia dan dapat meminimalisasi jumlah kerugian daerah yang diakibatkan oleh perbuatan melawan hukum yang dilakukan secara sengaja atau lalai oleh pemerintah daerah. Sebab, Pemerintah daerah akan lebih berhati-hati dalam menjaga keuangan negara yang pengelolaannya diserahkan kepadanya. Bentuk permasalahan tersebut perlu dilakukan pengubahan atau penggantian terhadap Peraturan Perundang-undangan.

Saran yang dapat diberikan adalah, pertama, perlunya pengubahan atau penggantian peraturan perundang-undangan dengan konstruksi yuridis yang konsisten mengenai Keuangan Negara, Keuangan Daerah, Kerugian negara, dan kerugian daerah. Kedua, perlunya pengubahan atau penggantian Peraturan Perundang-undangan dengan norma yang tegas mengenai perlunya penyetoran Kerugian Daerah ke kas negara.

\section{Daftar Pustaka}

\section{Buku}

Ali Zainuddin, H., Metode Penelitian Hukum, Sinar Grafika, Jakarta, 2011.

HR., Ridwan, Hukum Administrasi Negara Edisi revisi, Penerbit Rajawali Pers, cet. 14, Jakarta, 2018.

Huda, Ni'matul, Hukum Pemerintahan Daerah, Nusa media, Bandung, 2016.

Karianga, Hendra, Politik Hukum Dalam Pengelolaan Keuangan Daerah, Kencana Cetakan ke-1, Jakarta, 2013.

Mustaqiem, Hukum Keuangan Negara, Mata Padi Presindo, Yogyakarta, 2017.

Riawan Tjndra, W., Hukum Keuangan Negara, PT Grasindo, Jakarta, 2009.

\section{Jurnal}

Bahrullah Akbar dan Achmad Djazuli; Audit Keuangan Dan Kesejahteraan Rakyat Studi Pada Kabupaten Badung, Tabanan Dan Kota Denpasar 
Tahun 2013, Jurnal Tata kelola \& Akuntabilitas Keuangan Negara. Volume 1. Nomor 1. Juli 2015

Nurhasanah. Efektivitas Pengendalian Internal, Audit Internal, Karakteristik Instansi dan Kasus Korupsi (Studi Empiris di Kementerian/Lembaga), Jurnal Tata Kelola \& Akuntabilitas Keuangan Negara. Volume 2. Nomor 1. 2016

\section{Peraturan Perundang-undangan}

Undang-Undang Dasar 1945

Undang-Undang Nomor 17 Tahun 2003 Keuangan Negara, 5 April, Tahun 2003. Tambahan Lembaran Negara RI Nomor 47

Undang-Undang Nomor 1 Tahun 2004 Perbendaharaan Negara, 16 Oktober 2006. Tambahan Lembaran Negara RI. Nomor 4355

Undang-Undang Nomor 15 Tahun 2004 Pemeriksaan Pengelolaan dan Tanggung Jawab Keuangan Negara, Tanggal 16 Oktober 2006. Tambahan Lembaran Negara RI. Nomor 4400

PP Nomor 20 Tahun 2004 tentang Rencana Kerja Pemerintah Tanggal 09 Oktober 2004 Tambahan Lembaran Negara RI Nomor 4405

PP Nomor 21 Tahun 2004 tentang Penyusunan Rencana Kerja dan Anggaran Kementerian Negara/Lembaga Tanggal 5 Agustus 2004. Nomor 74. Tambahan Lembaran Negara RI Nomor 4405. 